\author{
Krzysztof Parzych \\ Pomeranian University in Słupsk \\ Institute of Geography \\ e-mail: krzysztof-parzych@wp.pl
}

\title{
DETERMINANTS OF THE TOURISM ACTIVITY OF SCHOOL PUPILS (AGED 15-19) FROM SŁUPSK AND CZĘSTOCHOWA
}

\begin{abstract}
The purpose of this article is to describe the different types of tourism undertaken by school pupils (aged 15-19) through the example of their tourism trips. Two cities were used: Słupsk and Częstochowa. Analyses of the differing forms of tourism have been made in the context of geographical, socio-economic and demographic determinants for both cities.
\end{abstract}

Key words: tourism types, determinants of tourism types, school pupils.

Participation rates, together with the demographic, economic and spatial determinants of tourism, play a crucial role in academic research. This issue has been and remains a subject of interest for tourism geography, sociology, psychology, pedagogy, economics and other disciplines. KRZYMOWSKA-KOSTROWICKA (1997) distinguishes two major groups of determinants of tourism behaviour: endogenous (genetic and physiological) and exogenous (environmental and socio-cultural).

School pupils (aged 15-19) are one of the most touristically-active groups in society in terms of degree of participation and the diversity of tourism types. The results of much recent research confirms this (ЕACIAK $2003,2005)$ and has been either in the form of single case studies (LUBOWICZ 1999, 2000, 2001; MATCZAK $1993,1996)$ or at a national level (EACIAK 2003, 2005).

This article deals with the issue of youth tourism and is based on comparative research into the tourism activity of pupils from two cities (Słupsk and Częstochowa) that differ both geographically and socioeconomically. This choice was made to attempt to show the role of the place of residence, in terms of the demographic and socio-economic features of the pupils and their immediate neighbourhood, as well as the physical-geographical context of their home cities, and their influence on tourism activity and participation. The article focuses on two main issues:

- the identification of school pupils' tourism activity and participation, measured at different times of the year (summer holidays 2001, Christmas 2001, winter holidays 2002, Easter 2002 and on all other days off from school - including weekends - during the 2001/ 2 school year);
- the determination of the main factors behind pupils' tourism activity and participation, considering the demographic, socio-economic and physical-geographical determinants of their home cities and their influence.

The results of a questionnaire survey undertaken in May and June 2002, in Słupsk and Częstochowa, in all państwowe licea ogólnoksztatcace (state upper secondary schools - general not technical or vocational), were the source of the data. The sample population was just under 2000 (1412 from Częstochowa and 550 from Słupsk) and the questionnaire survey was systematic, stratified and proportional. One part of the questionnaire was handed over directly to pupils for completion; another went to their class tutors who were appropriately instructed. A further survey was taken to supplement this research when the same schools were asked on the role educational institutions play in tourism trips organized for or by their pupils.

School pupils are an interesting research group as they have specific features in terms of their tourism activity, mainly as they have a lot of leisure time compared to other social groups. Furthermore they are learning behaviour and attitudes to leisure time culture (with tourism activity being a part of it) as they mature and come into adulthood.

The tourism activity of pupils is determined by many factors which can stimulate their involvement. According to LUBOWICZ (1990) in the case of pupils from schools, the main determinants are place of residence (urban or rural), family tourism traditions, introduction to tourism, further experience and sources of information. WARTECKA-WAŻYNSKA (2002) distinguishes three groups of factors which stimulate 
involvement: economic, social-psychological and organizational-institutional. SEWERYN (2004), among factors influencing tourism in society, mentions external (progress in transport, amount of leisure time, supply of tourism services together with their availability, quality and price, current fashion, mass media influence) and internal (psychological, demographic, socio-professional and environmental). According to DENEK (1989), tourism is a function of geographical conditions, demographic factors, time free from education, the level of economic development, communication, and the state social policy.

In the article it is assumed that the socio-economic context of pupils and their families, demographic variables, the geographical (landscape) factor associated with their place of residence, issues of a psychological nature (individuality), and the availability of destinations with the preferred advantages, are among the factors influencing tourism activity and participation. These were investigated for the tourism trips of pupils in the summer holidays of 2001, Christmas 2001, winter holidays 2002, Easter 2002, and trips made on weekends and days off during the school year 2001/2.

Furthermore, detailed analyses were made concerning what determined the tourism activity taken by pupils based on demographic and socio-economic features of the samples from each city. In the analysis the respondents referred to summer holidays, as participation in trips is at its highest around this time.

Summer holidays are the period when pupils are touristically most active. Around this time of year the fundamental factors having an influence on the potential tourism activity of pupils are:

- plenty of free time compared with other periods of the year - a result of the long holiday break at schools;

- the best weather conditions of the year which enables involvement in different types of tourism;

- the greatest availability of tourism accommodation and so on, both in Poland's tourism regions and abroad;

- the opportunity for long-term stays, not only short-term trips;

- the possibility for choosing types of tourism activity of varied expense, a result of the multitude of 'products' on the tourism market.

These factors create many opportunities to get involved in both domestic and foreign tourism which is confirmed by statistics from the Instytut Turystyki (Institute of Tourism). According to the Institute, from 1996 to 2002 , around $80 \%$ of young people aged 15-19, and $76 \%$ in 2002 alone, were involved in tourism (EACIAK 2003). Other authors (ABDEL-GHAFFAR 1992, CARR 1998, 2002, HORAK et al. 1989, LUBAŃSKI 1986, LUBOWICZ 1999, ŁOBOŻEWICZ 1996, RICHARDS \& WILSON 2003, RÓŻYCKI 2001, SEEKINGS 1998) published results that tend to confirm a high involvement in the summer holiday season.

Participation on tourism trips is high for both cities, however pupils residing in Częstochowa show higher levels (Table I). This can be explained by better transport availability, and as a consequence in terms of time and money, access to the most important areas of 'tourism penetration' in both Poland and Europe, and also by the greater level of economic development in Częstochowa and its region with a consequent higher standard of living. Differences in tourism activity are also obvious from the demographic and socioeconomic structures for both cities.

T a b l e 1. Tourism participation of pupils from Słupsk and Częstochowa

\begin{tabular}{|l|c|c|c|c|c|}
\hline & $\begin{array}{c}\text { Summer } \\
\text { break } \\
2001\end{array}$ & $\begin{array}{c}\text { Christmas } \\
2001\end{array}$ & $\begin{array}{c}\text { Easter } \\
2002\end{array}$ & $\begin{array}{c}\text { Winter } \\
\text { break } \\
2002\end{array}$ & $\begin{array}{c}\text { School } \\
\text { year } \\
2001 / 2\end{array}$ \\
\hline $\begin{array}{l}\text { Pupils from } \\
\text { Częstochowa }\end{array}$ & 70.70 & 6.90 & 8.90 & 22.60 & 33.90 \\
\hline $\begin{array}{l}\text { Pupils from } \\
\text { Słupsk }\end{array}$ & 62.00 & 6.30 & 9.90 & 15.90 & 33.40 \\
\hline
\end{tabular}

So u r c e: Personal research based on results of the questionnaire survey.

To investigate the determinants of pupils' tourism activity, the correlation between it and demographic and socio-economic variables was examined. The analysis of the factors influencing participation in the 2001 summer holidays included gender but showed that patterns for male and female pupils are similar. In Słupsk it was $62.0 \%$ and $60.9 \%$ respectively while in Częstochowa, $71.3 \%$ and $70.2 \%$. Gender then does not have any major influence.

What does make a difference however is the size of family in which the pupils were brought up, confirmed by a highly negative correlation between tourism participation in the summer holiday season and the size of family. For both cities a coefficient of $r=-0.88$ was found and from this it can be concluded that pupils from larger families hardly took part in tourism in the summer of 2001, usually a result of the lower material status of such families.

Socio-economic factors are important determinants of tourism involvement (LUBOWICZ 1990, 1996, 1999, ZAWADZKI et al., Table I). While studying involvement in tourism of Słupsk and Częstochowa school pupils, correlations between tourism activity and participation and information on parents' education, material status, background and place of residence (urban or rural) were made.

Much greater tourism activity is usually found for pupils from families with better material status: $63 \%$ from Słupsk and 72\% from Częstochowa. For those from families with a lower material status, it is 
$51 \%$ and $62 \%$ respectively. The Pearson correlation coefficients are high ( $r=0.86$ for both cities) which tends to confirm the thesis that the material situation does matter when it comes to participation in tourism. Furthermore, important relations between participation in tourism during the summer holiday and in other periods were observed for teenagers from materially better-off families. This can be found in the ANOVA test results (Table II) where the relation is statistically significant. Pupils with better material support travelled more often in the summer holidays as well as at other times of the year.

T a b le 2. ANOVA test results: correlation between tourism participation in different seasons and the material status of pupils from Słupsk and Częstochowa

\begin{tabular}{|l|c|c|}
\hline \multicolumn{1}{|c|}{ ANOVA test results } & Value & $\begin{array}{c}\text { Level of } \\
\text { significance }\end{array}$ \\
\hline $\begin{array}{l}\text { Number of trips during summer } \\
\text { break }\end{array}$ & 14.379 & 0.000 \\
\hline Number of trips during winter break & 5.869 & 0.001 \\
\hline Number of trips during school year & 6.450 & 0.000 \\
\hline
\end{tabular}

S o u r c e: Personal research based on the questionnaire survey.

Among socio-economic factors, parents' education level has the greatest importance and strongest influence. Confirmation can be found for this thesis when we look at tourism involvement levels for pupils whose parents have both had university education: $73 \%$ for pupils in Słupsk and 83\% for Częstochowa. On the contrary, if both parents had a vocational education only, the figures are $43 \%$ and $73 \%$.

T a b l e 3. Tourism activity ratios for pupils from Słupsk and Częstochowa

\begin{tabular}{|l|c|c|}
\hline \multirow{2}{*}{} & \multicolumn{2}{|c|}{ Average number of trips } \\
\cline { 2 - 3 } & $\begin{array}{c}\text { Pupils } \\
\text { from Słupsk }\end{array}$ & $\begin{array}{c}\text { Pupils from } \\
\text { Częstochowa }\end{array}$ \\
\hline Summer break 2001 & 1.69 & 1.55 \\
\hline Easter 2002 & 1.00 & 1.00 \\
\hline Christmas 2001 & 1.00 & 1.00 \\
\hline Winter break 2002 & 1.04 & 1.05 \\
\hline School year 2001/2 & 1.37 & 1.33 \\
\hline
\end{tabular}

S o u r c e: Personal research based on the questionnaire survey.

For school pupils from Słupsk 586 trips were made during the summer holidays of 2001 alone: 1.69 per pupil. For pupils from Częstochowa the figure is a little higher (Table III). In Słupsk $49.1 \%$ took part in one trip, $32.2 \%$ in two trips, $14.3 \%$ in three, and $4.4 \%$ in at least four. School pupils from Częstochowa, about 1000 pupils (70.8\% of the sample), made a total of 1563 trips: 1.55 per pupil (Table III). Pupils often made one trip only $-58.2 \%$, two trips $-29.2 \%$, three $-10.0 \%$, and only about $0.4 \%$ made four trips or more. There are differences in the levels of tourism activity and participation between the cities.

A lot more pupils from Częstochowa took part in tourism, nevertheless pupils from Słupsk who did participate travelled more often which may mean that being involved in tourism has a more exclusive importance for this group of pupils. To supplement our analysis of tourism activity and participation, and its determinants, here are some data explaining why some of the pupils were not involved in tourism in given periods of time (Table IV).

\section{T a b l e 4. Main reasons for not being involved in tourism by pupils from Słupsk and Częstochowa during the summer holiday season in 2001 (in \%)}

\begin{tabular}{|l|c|c|}
\hline $\begin{array}{c}\text { Reasons for not being } \\
\text { involved in tourism }\end{array}$ & $\begin{array}{c}\text { Pupils from } \\
\text { Słupsk }\end{array}$ & $\begin{array}{c}\text { Pupils from } \\
\text { Częstochowa }\end{array}$ \\
\hline Lack of time & 5.30 & 12.10 \\
\hline Material reasons & 29.70 & 36.00 \\
\hline Lack of need & 24.30 & 21.30 \\
\hline Family reasons & 4.00 & 4.60 \\
\hline Health problems & 0.40 & 2.40 \\
\hline
\end{tabular}

S o u r c e: Personal research based on the questionnaire survey.

The most common reasons for not taking part for pupils from Słupsk were: material reasons, no need to travel, and lack of time. The same reasons were given by pupils of Częstochowa as an explanation too so the reasons from pupils of the two cities are close. ALEJZIAK (1991), LUBOWICZ (1990, 1999), ŁACIAK (2005), ŁOBOŻEWICZ (1985), RÓŻYCKI (2001), ZAWADZKI (2001), have also pointed to the same reasons for a lack of involvement in tourism.

The duration of the journey was a crucial factor for getting involved in tourism involvement in the summer holiday season (Table V).

In the duration terminology of tourism research, short term (1-4 days) and long-term (above 5 days) trips are distinguished. In the present analysis longterm trips were additionally divided into 5-7 days, 813 days, 14-21 days, trips longer than 21 days, lasting more than one month and covering the entire holidays.

During the summer break of 2001 the majority of pupils made $8-13$ days trips $(33.4 \%$ pupils from Częstochowa and 31.3\% from Słupsk). Also frequent were trips lasting 14-21 days or 5-7 days. It is noticeable that pupils from Słupsk took part in shortterm trips much more often and also in the category lasting over one month (8.3\% pupils in Słupsk; $2.7 \%$ in Częstochowa). 
$\mathrm{T} \mathrm{a} \mathrm{b} \mathrm{l} \mathrm{e} \mathrm{5.} \mathrm{The} \mathrm{duration} \mathrm{of} \mathrm{tourism} \mathrm{trips} \mathrm{for} \mathrm{pupils} \mathrm{from} \mathrm{Słupsk}$ and Częstochowa during the summer holiday of 2001

\begin{tabular}{|l|c|c|}
\hline \multicolumn{1}{|c|}{$\begin{array}{c}\text { Duration } \\
\text { of trip }\end{array}$} & $\begin{array}{c}\text { Pupils from } \\
\text { Słupsk } \\
\text { (\% of all trips) }\end{array}$ & $\begin{array}{c}\text { Pupils from } \\
\text { Częstochowa } \\
\text { (\% of all trips) }\end{array}$ \\
\hline $1-4$ days & 11.50 & 6.70 \\
\hline $5-7$ & 23.30 & 24.90 \\
\hline $8-13$ & 31.30 & 33.40 \\
\hline $14-21$ & 20.70 & 26.50 \\
\hline $22-30$ & 4.90 & 4.50 \\
\hline Over one month & 8.30 & 2.70 \\
\hline All summer break & 0.00 & 1.30 \\
\hline
\end{tabular}

S o u r c e: Personal research based on the questionnaire survey.

Less pupils from Słupsk took part in summer holiday trips, but at the same time those who did made more trips which lasted longer, which may suggest their tourism involvement was more strongly related to material status than those of pupils from Częstochowa.

T a ble 6. ANOVA test results: the relation between the number of holiday trips taken by pupils from Słupsk and Częstochowa and their parents' level of education

\begin{tabular}{|l|c|c|}
\hline \multicolumn{1}{|c|}{ ANOVA test results } & Value & $\begin{array}{c}\text { Level } \\
\text { of significance }\end{array}$ \\
\hline $\begin{array}{l}\text { Number of trips during } \\
\text { summer break }\end{array}$ & 23.115 & 0.000 \\
\hline $\begin{array}{l}\text { Number of trips during } \\
\text { winter break }\end{array}$ & 9.494 & 0.000 \\
\hline $\begin{array}{l}\text { Number of trips during } \\
\text { school year }\end{array}$ & 2.965 & 0.019 \\
\hline
\end{tabular}

S o u r c e: Personal research based on the questionnaire survey.

The duration and number of trips were correlated with socio-economic variables. There are strong, significant correlations between material status and parents' educational level, and with how many trips were made during the summer, winter and during the school year 2001/2 (Table VI). There were also indicators showing the importance of place of residence and the influence it has on tourism involvement during the summer holidays (Table VII). This applies to school pupils in Słupsk, although there are big differences between pupils living in Słupsk and outside of the city, when it comes to travelling abroad.

Pupils living outside the city of Słupsk took part in foreign trips very seldom, probably a result of their lower material status. When it comes to pupils living inside and outside of Częstochowa, their tourism participation and the taking of foreign trips are on a similar level, perhaps pointing to the fact that material differences are smaller.

Duration and material status are closely related. This factor has more meaning when it comes to pupils
T a b l e 7. The number of summer holiday trips for pupils from Słupsk and Częstochowa related to their place of residence, and both domestic and foreign trips (in \%)

\begin{tabular}{|l|c|c|}
\hline \multirow{2}{*}{ Place of residence } & \multicolumn{2}{|c|}{$\begin{array}{c}\text { Participation in domestic } \\
\text { and foreign trips (\%) }\end{array}$} \\
\cline { 2 - 3 } & domestic & foreign \\
\hline Słupsk & 76.5 & 23.5 \\
\hline Outside Słupsk & 96.4 & 3.6 \\
\hline Częstochowa & 81.3 & 18.7 \\
\hline Outside Częstochowa & 79.7 & 20.3 \\
\hline
\end{tabular}

S o u r c e: Personal research based on the questionnaire survey.

from Słupsk, and the coefficient there was higher $(r=$ 0.86). In the tested group of pupils from Częstochowa, these variables are correlated only moderately $(r=0.50)$.

The level of parents education is a stronger determinant of the duration of trips in Słupsk $(r=0.17$ in Częstochowa; $r=0.45$ in Słupsk). Differences in trip duration and length are more visible when contrasting pupils living within both cities and outside of them.

Pupils living outside of Słupsk made shorter summer holiday trips than those living in Słupsk. However, when it comes to pupils from Częstochowa, this factor has less statistical value as can be seen from the chi square test (Table VIII).

This situation indicates a much greater disproportion between pupils from within and outside of Słupsk, considering the duration of trips, which probably points at differences in their material status as the main factor. The same is not true for Częstochowa which may be a result of their more similar material status.

T a b l e 8 . Chi square test values between trip length and place of residence for pupils from Słupsk and Częstochowa

\begin{tabular}{|l|c|c|}
\hline \multicolumn{1}{|c|}{ Specification } & $\begin{array}{c}\text { Pupils from } \\
\text { Słupsk }\end{array}$ & $\begin{array}{c}\text { Pupils from } \\
\text { Częstochowa }\end{array}$ \\
\hline Chi square test value & 0.783 & 6.21 \\
\hline Level of significance & 0.012 & 0.08 \\
\hline
\end{tabular}

S o u r c e: Personal research based on the questionnaire survey.

T a b l e 9. Of the Kruskala-Wallis test value for holiday trip duration and attractiveness to pupils from Słupsk and Częstochowa

\begin{tabular}{|l|c|}
\hline & $\begin{array}{c}\text { Attractiveness of the place visited } \\
\text { during last summer break }\end{array}$ \\
\hline Test value & 11.874 \\
\hline Level of significance & 0.037 \\
\hline
\end{tabular}

S o u r c e: Personal research based on the questionnaire survey.

The distance travelled on holiday trips is also significantly correlated with the attractiveness of the destination. The value of the Kruskala-Wallis test confirms it (Table IX). The longest journeys were more often taken to the most attractive tourism regions of Poland and Europe. 
Religious holidays are a specific time for engaging in tourism involvement. They are affected by the short time away from school on one side, and weather conditions on the other, which puts limits on trips and excursions when it comes to types of tourism and accessible destinations. Furthermore, in the Polish tradition spending Christmas and Easter with the family is crucial. Low figures for tourism involvement in these periods were noted $(6.3 \%$ for Słupsk; $6.9 \%$ for Częstochowa at Christmas - at Easter 8.9\% and 9.9\% respectively) confirm this thesis (Table I).

No clear relation between tourism involvement during Christmas and Easter and demographic and socio-economic factors was noted. Tourism involvement, taking demographic and socio-economic structures into consideration, shows no significant difference between the groups analysed and the rest of the population.

The tourism participation of Słupsk and Częstochowa pupils in the winter holidays was much higher than at the religious holidays (Table I). On account of the length of free time some pupils took more than one trip in this period, the majority however took one (about 91.3\% in Słupsk; 94.2\% in Częstochowa).

Analysis of tourism involvement indicators showed certain gender differences. During the winter holidays girls took trips more often $(17.0 \%$ female and $13.8 \%$ male in Słupsk; $23.0 \%$ and about $20.0 \%$ respectively in Częstochowa). Besides, pupils living inside both cities were more often involved in tourism in comparison to those living outside. About 20.3\% living in Słupsk itself and $24.6 \%$ in Częstochowa took part in tourism trips in the winter holidays. On account of the short period of the winter holiday, trips taken by Słupsk and Częstochowa pupils lasted from 4 to 7 days.

Amongst the reasons for no tourism trip being taken, the most frequent was 'lack of need' (42.0\% in Słupsk; $43.0 \%$ in Częstochowa). Amongst other causes were material considerations $(23.4 \%$ in Słupsk and $14.6 \%$ in Częstochowa) and lack of the time $(16.5 \%$ and $21.2 \%$ respectively).

The winter holidays are a period suitable for specialised tourism, dependent on the availability of appropriate conditions. On account of the shorter free time and higher costs, these trips were available only to a small group of pupils with a higher material status. This status clearly determined the tourism activity in the winter holidays, confirmed by high correlation coefficients ( $r=0.69$ for Słupsk; $r=0.94$ for Częstochowa). The lower coefficient for Słupsk could be the result of the much lower accessibility of mountains resorts which has formed a 'lack of habit' in the taking of journeys during winter holidays.

The period of the school year between 01.09.2001 and 01.09.2002 included trips during school time, public holidays and weekends. According to SOŁTYSIK (1999), trips at weekends are not popular among Polish pupils and the small role played by leisure time during weekends confirms the research of LUBAŃSKI (1986) \& BOSIACKI (1982). Tourism participation in the school year 2001/2 was very similar (Table I). The tourism involvement of Słupsk and Częstochowa pupils was diversified in terms of the number of trips, most popular time and length.

Material status was the factor most significantly determining tourism involvement during the school year confirmed by the correlation coefficients $(r=0.99$ for Słupsk; $r=0.84$ for Częstochowa). Moreover pupils from families with a higher material status took part in more then one trip. However when considering the whole population it was calculated that the majority took part in just one: 70\% from Słupsk, 76\% from Częstochowa; $20.2 \%$ and $16.0 \%$ respectively took part in two; and $4 \%$ and $1.8 \%$ in four or more.

Amongst reasons for not taking part were a lack of the time (34.2\% from Słupsk; $27.7 \%$ from Częstochowa) and material troubles $(24.7 \%$ and $31 \%$ respectively).

The analysis of tourism involvement during the 2001 summer holidays, the winter holidays and the remaining part of the school year of 2001/2 shows that their main determinants were the amount of leisure time, availability of destinations with preferred advantages, demographic and socio-economic factors (education of parents, material status, place of residence and family size) of pupils from Słupsk and Częstochowa and their families, and the tourism attractiveness of places visited. Differences in the level of the tourism involvement are small. Slightly higher tourism involvement of pupils from Częstochowa might indicate its higher material status.

The reasons for tourism involvement lie in the greater correlation with socio-economic and demographic features of pupils and their families, and with the availability and tourism attractiveness of destinations visited.

\section{BIBLIOGRAFIA}

ABDEL-GHAFFAR A., 1992, Youth Tourism, Annals of Tourism Research, 19(4), pp. 792-794.

ALEJZIAK W., 1991, Aktywność turystyczna mieszkańców Szwecji na przykładzie populacji sztokholmskiej - badania wstępne, Folia Turistica, 2, pp. 3-25.

BosiaCKI S., 1982, Czas wolny mieszkańców miast, Problemy Turystyki , 1/2, pp. 31-59.

CARR N., 1998, The Young Tourist: A Case of Neglected Research, Progress in Tourism and Hospitality Research, 4(4), pp. 307-318.

CARR N., 2002, A Comparative Analysis of the Behaviour of Domestic and International Young Tourists, Tourism Management, 23(3), pp. 321-325. 
DENEK K., 1989, Krajoznawstwo $i$ turystyka w wychowaniu dzieci i młodzieży szkolnej, Warszawa, 264 pp.

HORAK S., WeBER S., 2000, Youth Tourism in Europe: Problems and Prospects, Tourism Recreation Research, 25 (3), pp. 37-44.

HORAK S., CRNKOVIĆ S., MIKACIĆ, 1989, Rozwój turystyki młodzieżowej w Chorwacji, Problemy Turystyki, 2, pp. 37-44.

KRZYMOWSKA-KOSTROWICKA A., 1997, Zarys geoekologii rekreacji, Warszawa, 327 pp.

LUBAŃSKI K.,1986, Aktywność turystyczna a styl życia uczniów szkół ponadpodstawowych, Problemy Turystyki, 2, pp. 38-49

LUBOWICZ Z., 1990, Turystyka młodzieży polskiej lat osiemdziesiątych: społeczne uwarunkowania, Warszawa, 56 pp.

LUBOWICZ Z., 1996, Turystyka młodzieży szkół ponadpodstawowych w 1995 roku, Problemy Turystyki, 1-4, pp. 105-110.

LUBOWICZ Z., 1999, Badania wyjazdów turystycznych młodzieży szkól ponadpodstawowych, Problemy Turystyki , 2, pp. 21-24.

ŁACIAK J., 2003, Aktywność turystyczna dzieci i młodzieży w 2002 roku, Warszawa, $84 \mathrm{pp}$.

ŁACIAK J., 2005, Aktywność turystyczna dzieci i młodzieży w 2004 roku, Warszawa, 84 pp.

ŁOBOŻEWICZ T., 1985, Krajoznawstwo i turystyka w szkole, Warszawa, $327 \mathrm{pp}$.

ŁOBOŻEWICZ T., 1996, Turystyka dzieci i młodzieży szkolnej, Warszawa, $216 \mathrm{pp}$.

MAtczAK A., 1993, Percepcja przestrzeni turystycznej Polski przez młodzież licealną Łodzi, Turyzm, vol. 3, no. 2, pp. 61-77.
MATCZAK A., 1996, Percepcja regionalnej przestrzeni turystycznej przez uczniów szkół licealnych Łodzi, Turyzm, vol. 6, no. 1 .

RICHARDS G., WILSON J., 2003, Today's Youth Tourists: Tomorrow's Global Nomads? New Horizons in Independent Youth and Student Travel, Amsterdam. International Student Travel Confederation and Arnhem: Association of Tourism and Leisure Education, 24 pp.

RÓŻYCKI P., 2001, Miejsce turystyki w sposobie zagospodarowania czasu wolnego młodzieży szkół ponadpodstawowych Krakowa, Folia Turistica, 10, pp. 85-95.

SEEKINGS J., 1998, The Youth Travel Market, Travel and Tourism Analyst, 5, pp. 37-55.

SEWERYN R., 2004, Wewnętrzne wyznaczniki aktywności turystycznej Polaków, Problemy Turystyki, 3, pp. 15-32.

SOŁTYSIK M., 1999, Sposoby spędzania czasu wolnego przez młodzież szkolną Wrocławia w okresach weekendowych, [in:] Wybrane zagadnienia turystyki, Zeszyty Naukowe Wyższej Szkoły Zarządzania, Wrocław, pp. 95-114

WARTECKA-WAŻYŃSKA A., 2002, Aktywność turystyczna młodzieży szkół ponadpodstawowych, [in:] Gospodarka turystyczna w XXI wieku - stan obecny i perspektywy rozwoju, ed. S. Bosiacki, Poznań, pp. 141-152.

ZAWADZKI M., 2001, Aktywność turystyczna mieszkańców Polski w sezonie letnim 2001 roku, Problemy Turystyki, 1-2, pp. 105-109 . 